\title{
Article \\ Effect of Hot-Air Convective Drying on Activity Retention of Amylase and Invertase in Dried Mango of Varieties Sindri, SB Chaunsa, and Tommy Atkins
}

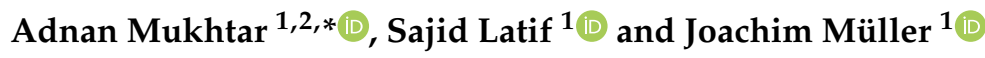 \\ 1 Tropics and Subtropics Group, Institute of Agricultural Engineering (440e), University of Hohenheim, \\ 70599 Stuttgart, Germany; s.latif@uni-hohenheim.de (S.L.); joachim.mueller@uni-hohenheim.de (J.M.) \\ 2 Sub-Campus Depalpur Okara, Institute of Horticulture Sciences, University of Agriculture Faisalabad, \\ Renala Khurd 56300, Pakistan \\ * Correspondence: adnan.mukhtar@uni-hohenheim.de or info440e@uni-hohenheim.de; \\ Tel.: +49-0711-459-24708
}

check for

updates

Citation: Mukhtar, A.; Latif, S.; Müller, J. Effect of Hot-Air

Convective Drying on Activity

Retention of Amylase and Invertase

in Dried Mango of Varieties Sindri, SB

Chaunsa, and Tommy Atkins. Appl.

Sci. 2021, 11, 6964. https://doi.org/

10.3390/app11156964

Academic Editors: Elisabete Maria de

Castro Lima and Jorge Manuel

Rosa de Medeiros

Received: 7 July 2021

Accepted: 26 July 2021

Published: 28 July 2021

Publisher's Note: MDPI stays neutral with regard to jurisdictional claims in published maps and institutional affiliations.

Copyright: (C) 2021 by the authors. Licensee MDPI, Basel, Switzerland. This article is an open access article distributed under the terms and conditions of the Creative Commons Attribution (CC BY) license (https:// creativecommons.org/licenses/by/ $4.0 /)$.

\begin{abstract}
Recently, fruit-drying industries are showing great interest in producing dry fruits that preserve a high enzyme content. Therefore, this study aimed to investigate the effect of hot-air convective drying on activity retention of amylase and invertase in dried mango of varieties Sindri, Samar Bahisht (SB) Chaunsa, and Tommy Atkins. Convection drying was conducted under over-flow mode at five temperatures $\left(40,50,60,70\right.$, and $\left.80{ }^{\circ} \mathrm{C}\right)$, two air velocities $\left(1.0\right.$ and $\left.1.4 \mathrm{~m} \mathrm{~s}^{-1}\right)$, and constant specific humidity of $10 \mathrm{~g} \mathrm{~kg}^{-1}$ dry air. The enzymatic degradation data were fitted to the first-order reaction kinetics model, in which the temperature dependence of the rate constant is modelled by the Arrhenius-type relationship. Results showed that the maximum amylase and invertase activity for dried mango of all three varieties was best preserved in samples dried at a temperature of $80^{\circ} \mathrm{C}$ and an air velocity of $1.4 \mathrm{~m} \mathrm{~s}^{-1}$. In contrast, a lower drying temperature and an air velocity of $1.0 \mathrm{~m} \mathrm{~s}^{-1}$ contributed to a significant decrease $(p<0.05)$. Exploration of different temperatures and air velocities to save amylase and invertase in dried mango is useful from an industrial point of view, as mango can be a natural dietary source of digestive enzymes to improve digestion.
\end{abstract}

Keywords: enzyme degradation; digestive enzyme; convective drying (over-flow); Sindri; Samar Bahisht Chaunsa; Tommy Atkins

\section{Introduction}

The market of industrially produced dried mango is steadily growing due to its good taste, unique flavor, attractive color, and nutritional value [1]. To produce high-quality dried mangoes, fruit-drying industries are paying special attention to the activity preservation of enzymes in the dried product. The ultimate challenge for the modern food industry is not only to minimize the degradation of beneficial enzymes, but also to maximize the preservation of these enzymes in the final dried product. As people are becoming more conscious of their diet, the use of enzyme supplements has also increased considerably in recent years. In this regard, raising consumer awareness and specifying a product by its nutrients (enzyme units) could have a substantial effect on increasing its demand. The advantage of producing dried mango, in which a high proportion of the enzymes amylase and invertase is retained, is that it can be used in a wide range of applications such as functional foods, bread making, brewing, food supplements, and animal feed.

As enzymes are proteins in nature, they must be characterized with regard to their temperature-dependent behavior. In this study, amylase and invertase were selected as the model enzymes. The selection was based on the enzymes that are most commonly studied in fresh mango of different varieties and are present in a concentration that is easy 
to measure [2,3]. In addition, amylase and invertase are the most important carbohydrate digestive enzymes, as they break down complex carbohydrates into simple sugars. Hence, mango flesh can contribute as a source of natural digestive enzymes.

Fresh mango is extremely perishable and susceptible to rapid decay due to ripening and biochemical degradation, resulting in a poor shelf life. Thus, in order to consume this fruit all year long, drying is widely used technology in food processing and preservation. To date, several drying methods, such as hot-air convective drying, infrared drying, vacuum drying, microwave drying, and freeze drying have been applied to fruits, vegetables, and herbs to prepare dehydrated products [4-8]. However, convective-air drying is most commonly used due to its easy operation, as well as low investment and operating costs [9]. It is also well known that hot-air drying is primarily influenced by the drying temperature and air velocity [10-12], whereas specific humidity has no major influence on the drying rate, except that its higher value decreases the drying rate [13]. Mango and other tropical fruits are commonly dried at temperatures ranging $40{ }^{\circ} \mathrm{C}$ to $80{ }^{\circ} \mathrm{C}$, and air velocities of

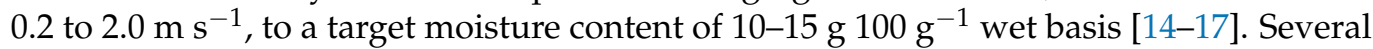
researchers have extensively documented the effects of the selected drying conditions on the physicochemical and nutritional parameters of dried mango [6,15,18-20]. Only a few studies, however, focus on the enzymatic activity in particular. In most of these studies, considerable efforts have been undertaken to understand the inactivation of the enzymes during fruit drying [21-23]. However, to the best of our knowledge, no study is available dealing with the effect of drying temperature and air velocity on the activity retention of amylase and invertase in dried mango. As enzymes are very diverse in nature, drying at different temperatures and air velocities could contribute to different degradation rates of enzymes due to differences in drying time, exposure to heat, light, and oxidation. Consequently, the activity preservation of the enzymes in the final dried product may be significantly affected under different drying conditions. Therefore, it is highly important to obtain information about the drying operating parameters and its relationship with activity retention of enzymes in dried mango, due to the health benefits of the enzymes.

The aim of the present study is specifically focused on investigating and comparing the effect of the most influential hot-air drying parameters, such as temperature and air velocity, on the activity retention of amylase and invertase in dried mango slabs. The results from this research work will provide information to select the appropriate drying temperature and velocity to preserve a maximum of the digestive enzymes, amylase, and invertase in dried mango.

\section{Materials and Methods}

\subsection{Raw Materials}

Mangoes (Mangifera indica L.) from three varieties, Sindri, Samar Bahisht (SB) Chaunsa, and Tommy Atkins, were used for this study. Sindri and Samar Bahisht (SB) Chaunsa were harvested from Khanewal, Pakistan, and transported by air to Frankfurt, Germany, where they were obtained through local shipment. However, Tommy Atkins was purchased from a local market in Stuttgart, Germany. During the experiments, the fruits were refrigerated at a temperature of $11 \pm 1{ }^{\circ} \mathrm{C}$ for no more than six weeks.

\subsection{Drying Experiments}

Convective drying was carried out using an over-flow chamber of a high precision hot-air laboratory dryer designed at the Institute of Agricultural Engineering, University of Hohenheim, Stuttgart, Germany [24], which ensured a highly accurate control of the temperature, humidity, and velocity of the drying air. Before drying, the average initial moisture contents (Sindri $86.96 \pm 2.05$, SB Chaunsa $82.12 \pm 2.62$, and Tommy Atkins $89.08 \pm 2.22 \%$ w.b.) were measured when drying $24 \mathrm{~h}$ in an oven at $105^{\circ} \mathrm{C}$ [25], as well as the total soluble solids (Sindri $17.33 \pm 1.71$, SB Chaunsa $20.69 \pm 1.46$, and Tommy Atkins $13.95 \pm 2.81$ degree Brix) by digital refractometer (ATAGO PR-201 palette, ATAGO Co. Ltd., Tokyo, Japan) and the water activity (Sindri $0.922 \pm 0.012$, SB Chaunsa $0.920 \pm 0.010$, and 
Tommy Atkins $0.937 \pm 0.012$ ) using a ventilated hygrometer system (Rotronic A2, Rotronic AG, Basserdorf, Switzerland) after $30 \mathrm{~min}$ in a thermostatic cell at $23^{\circ} \mathrm{C}$.

For drying, fruits were cut into slabs of $4 \mathrm{~cm} \times 2 \mathrm{~cm} \times 0.8 \mathrm{~cm}$ using a stainless steel knife and a food dicer (MultiSchneider Serano 7, Ritter, Groebenzell, Germany). A fixed dimension of mango slabs was used to achieve more homogeneity of the dried samples, as fruit size and shape affect drying time and fruit quality loss by interfering with the convective drying process [26]. Drying experiments were performed in duplication by employing different temperatures $\left(40,50,60,70\right.$, and $\left.80^{\circ} \mathrm{C}\right)$ and air velocities $(1.0$ and $1.4 \mathrm{~m} \mathrm{~s}^{-1}$ ), while maintaining a constant specific humidity $10 \mathrm{~g} \mathrm{~kg}^{-1}$. As specific humidity might vary over the experimental days, a constant specific humidity was set, which is a typical value at temperate latitudes. During the dehydration process, mass reduction was automatically recorded at a regular interval of $15 \mathrm{~min}$ until the target moisture content of approximately $11 \%$ wet basis was achieved [2]. This moisture content is usually considered to be under the hygienically safe microbial load with a water activity of $\leq 0.6[27,28]$. Final samples were cooled, packed in airtight polyethylene bags, and stored in a dark place at room temperature before use.

\subsection{Enzyme Extraction in Fresh and Dried Mango}

The selected enzymes, amylase and invertase, were extracted according to the modified method of Hossain et al. [3]. Taking 120 mangoes per variety, twenty extractions were prepared for fresh and dried mango of all three varieties. For the preparation of each extraction from fresh samples, the flesh from six mangoes was randomly selected, cut into small pieces and homogenized with the help of a vortex mixer (Polytron 2500E, Kinematica, Luzern, Switzerland). The resultant homogenate $10 \mathrm{~g}$ ( $1.8 \mathrm{~g}$ dry matter) was added to a falcon tube with $10 \mathrm{~mL}$ of extraction buffer (0.1 M Potassium phosphate buffer, $\mathrm{pH} 7.0)$. After mixing with a vortex mixer for $3 \mathrm{~min}$, the samples were further centrifuged (Z326K, HERMLE Labortechnik GmbH, Wehingen, Germany) at 13,400 rpm for $10 \mathrm{~min}$ at $4{ }^{\circ} \mathrm{C}$. The supernatants were collected and run separately in triplicates to test the amylase and invertase activity. For dried samples, different dried slabs from the same treatment were randomly selected, cut into small pieces, chopped and mixed with the help of a mixer. Next, $1.96 \mathrm{~g}$ ( 1.8 $\mathrm{g}$ dry matter) of the dried mixture was homogenized into $10 \mathrm{~mL}$ of extraction buffer, centrifuged under the same defined conditions. The supernatant was collected to test the enzyme activity in the dried samples.

\subsection{Amylase Activity Assay}

Amylase activity was evaluated by estimating the release of maltose calculated from the standard curve prepared by using maltose at concentrations of $0-6 \mathrm{mg} \mathrm{ml}^{-1}$ [29]. One percent $(w / v)$ starch solution was used as a substrate. Twenty freshly prepared enzyme extracts (Section 2.3.) were analyzed separately in triplicate to measure amylase activity in fresh and dried mango of all three varieties. For each activity assay, $2.9 \mathrm{~mL}$ of starch solution were mixed with $100 \mu \mathrm{L}$ of enzyme extract and incubated at $37^{\circ} \mathrm{C}$ for $10 \mathrm{~min}$. Then, after adding $1 \mathrm{~mL}$ of 3,5-dinitrosalicylic acid, it was further heated in boiling water for $5 \mathrm{~min}$ to complete the reaction. The reaction mixture was allowed to cool at room temperature and $9 \mathrm{~mL}$ of water were added to make a dilution. The mixture absorbance measured at $540 \mathrm{~nm}$ by a spectrophotometer (DR-6000, Hach Lange GmbH, Berlin, Germany) and a sample without enzyme extract was used as a control. One unit of enzyme activity was defined as the amount of enzyme required to release $1 \mathrm{mg}$ of maltose per min per $\mathrm{g}$ of sample at $37^{\circ} \mathrm{C}$.

\subsection{Invertase Activity Assay}

Invertase activity was measured by estimating the release of glucose calculated from the standard curve prepared by glucose at concentrations of $0-2.5 \mathrm{mg} \mathrm{m}^{-1}$ [29]. One percent $(w / v)$ sucrose solution was used as a substrate. Twenty freshly prepared enzyme extracts (Section 2.3.) were tested separately in triplicate to measure invertase activity in fresh and dried mango of all three varieties. For each invertase activity assay, $2.9 \mathrm{~mL}$ of 
sucrose solution and $100 \mu \mathrm{L}$ of enzyme extract were mixed and incubated at $37{ }^{\circ} \mathrm{C}$ for 10 min. Next, $1 \mathrm{~mL}$ of 3,5-dinitrosalicylic acid was added and heated in boiling water for $5 \mathrm{~min}$ to complete the reaction. After cooling to room temperature, the mixture was diluted by adding $9 \mathrm{~mL}$ of water. The absorbance was recorded at $575 \mathrm{~nm}$ by a spectrophotometer (DR-6000, Hach Lange GmbH, Berlin, Germany) against the reaction mixture. The sample without enzyme extract was used as a control. One unit of enzyme activity was defined as the amount of enzyme required to release $1 \mathrm{mg}$ of glucose per min per $\mathrm{g}$ of sample at $37^{\circ} \mathrm{C}$.

\subsection{Kinetics Considerations of Amylase and Invertase}

The kinetics or destruction rate of amylase and invertase was also investigated for the variety Sindri during hot air convective drying. The samples were collected at regular 2-h intervals at $40^{\circ} \mathrm{C}$ and 1-h intervals at $60^{\circ} \mathrm{C}$ and $80^{\circ} \mathrm{C}$ for analysis of residual enzyme activity. The thermal degradation was expressed by a first-order kinetic model [30]:

$$
A / A_{o}=\exp \left(-k_{d} \times t\right),
$$

where $A$ is the residual activity after the treatment time $t(\mathrm{~min}), \mathrm{A}_{\mathrm{o}}$ is the initial activity, and $\mathrm{k}_{\mathrm{d}}$ is the deactivation or destruction rate constant $\left(\mathrm{min}^{-1}\right)$. The deactivation rate constant $\left(\mathrm{k}_{\mathrm{d}}\right)$ is temperature-dependent according to Arrhenius-equations [31]:

$$
\mathrm{k}_{\mathrm{d}}=\mathrm{k}_{\mathrm{do}} \times \exp \left(-\mathrm{E}_{\mathrm{d}} / \mathrm{RT}\right),
$$

where $\mathrm{k}_{\mathrm{d}}$ is the deactivation rate constant $\left(\mathrm{min}^{-1}\right), \mathrm{k}_{\mathrm{do}}$ is the pre-exponential factor, $\mathrm{E}_{\mathrm{d}}$ is the energy of deactivations $\left(\mathrm{J} \mathrm{mol}^{-1}\right), \mathrm{R}$ is the universal gas constant $8.314\left(\mathrm{~J} \mathrm{~mol}^{-1} \mathrm{~K}^{-1}\right)$, and $\mathrm{T}$ is the absolute temperature $(\mathrm{K})$.

\subsection{Maltose and Glucose Concentrations in Fresh and Dried Mango}

Maltose and glucose concentrations in Sindri, SB Chaunsa, and Tommy Atkins were determined by using the dinitrosalicylic acid method [32]. Six extractions were prepared for each of the fresh samples and those were dried at $40^{\circ} \mathrm{C}, 60^{\circ} \mathrm{C}$, and $80^{\circ} \mathrm{C}$ by following the same defined conditions (Section 2.3). The supernatant was collected and run separately to test the maltose and glucose concentrations. For the assay, $100 \mu \mathrm{L}$ of the extracted supernatant from fresh and dried samples, $2.9 \mathrm{~mL}$ of water and $1 \mathrm{~mL}$ of 3,5-dinitrosalicylic acid color reagent were pipetted into the test tubes. The reaction mixtures were mixed well with the help of a vortex mixer. The test tubes were heated for $5 \mathrm{~min}$ in a boiling water bath and after cooling to room temperature, the reaction mixture was diluted by adding $9 \mathrm{~mL}$ of water. The absorbance was measured against the reaction mixture at $540 \mathrm{~nm}$ for maltose and $575 \mathrm{~nm}$ for glucose by a spectrophotometer (DR-6000, Hach Lange GmbH, Berlin, Germany). The concentration of maltose and glucose was estimated from the calibration curve obtained by different concentrations of maltose $\left(y=4.1892 x-0.3397, R^{2}=0.9997\right)$ and glucose $\left(y=8.6824 x-0.4638, R^{2}=0.9981\right)$.

\subsection{Statistical Analysis}

The statistical analysis was performed by analysis of variance (ANOVA) and Tukey's honestly significant difference (HSD) test using IBM statistical package SPSS 22.0 at $p<0.05$ significance level. The data were plotted by using Origin Pro 2020 (OriginLab Co., Northampton, MA, USA).

\section{Results and Discussion}

\subsection{Amylase Activity in Fresh and Dried Samples}

Figure 1 shows the amylase activity in fresh and dried samples of the varieties Sindri, SB Chaunsa, and Tommy Atkins. For the fresh samples, SB Chaunsa displayed the highest activity (4.08-4.66 units $\mathrm{min}^{-1} \mathrm{~g}^{-1}$ ), followed by Tommy Atkins (2.10-2.95 units $\left.\min ^{-1} \mathrm{~g}^{-1}\right)$, whereas Sindri revealed the lowest activity $\left(1.09-2.15\right.$ units $\left.\mathrm{min}^{-1} \mathrm{~g}^{-1}\right)$. This finding may be due to the differences in varieties, climatic origin, and compositional varia- 
tions. Similar results were also observed in previous studies for fresh mango by Hossain et al. [3] and De Lima et al. [33]. However, after hot-air convective drying, the amylase activity of the dried samples was distinctly influenced by the drying temperature and air velocity. At drying temperatures from $40{ }^{\circ} \mathrm{C}$ to $80^{\circ} \mathrm{C}$ and an air velocity of $1.0 \mathrm{~m} \mathrm{~s}^{-1}$, the highest amylase activity $\left(4.67 \pm 0.49,4.30 \pm 0.46\right.$, and $7.22 \pm 0.73$ units $\min ^{-1} \mathrm{~g}^{-1}$, respectively) in all three varieties was preserved in samples dried at $80^{\circ} \mathrm{C}$, and the lowest $\left(3.33 \pm 0.14,3.07 \pm 0.37\right.$, and $4.93 \pm 0.94$ units $\mathrm{min}^{-1} \mathrm{~g}^{-1}$, respectively) was observed in samples dried at $40{ }^{\circ} \mathrm{C}$. This could be delineated by the fact that drying at $80^{\circ} \mathrm{C}$ required a shorter drying time $(277 \pm 35 \mathrm{~min})$ than drying at $40{ }^{\circ} \mathrm{C}(965 \pm 171 \mathrm{~min})$ [2]. As amylase is a heat-resistant enzyme, a decrease in drying time has a positive effect on the activity retention of amylase in dried samples. It is also generally known that the thermal stability of heat-resistant enzymes is markedly enhanced as a result of water evaporation [34,35]. This means that rapid water evaporation at higher drying temperatures contributes to a better preservation of enzyme activity. However, the elevated drying temperature must not be greater than the resistance limit. Alternatively, prolonged drying time at low temperature is associated with the degradation of amylase, which may be attributed to many different reasons that include the longer exposure to heat or oxidation, low water evaporation rate, product accumulation, unavailability of the substrate, and other physicochemical alterations. The related results were also reported by Samborska et al. [36] that extending drying times and high moisture content enhanced amylase degradation during drying of commercial fungal alpha-amylase.
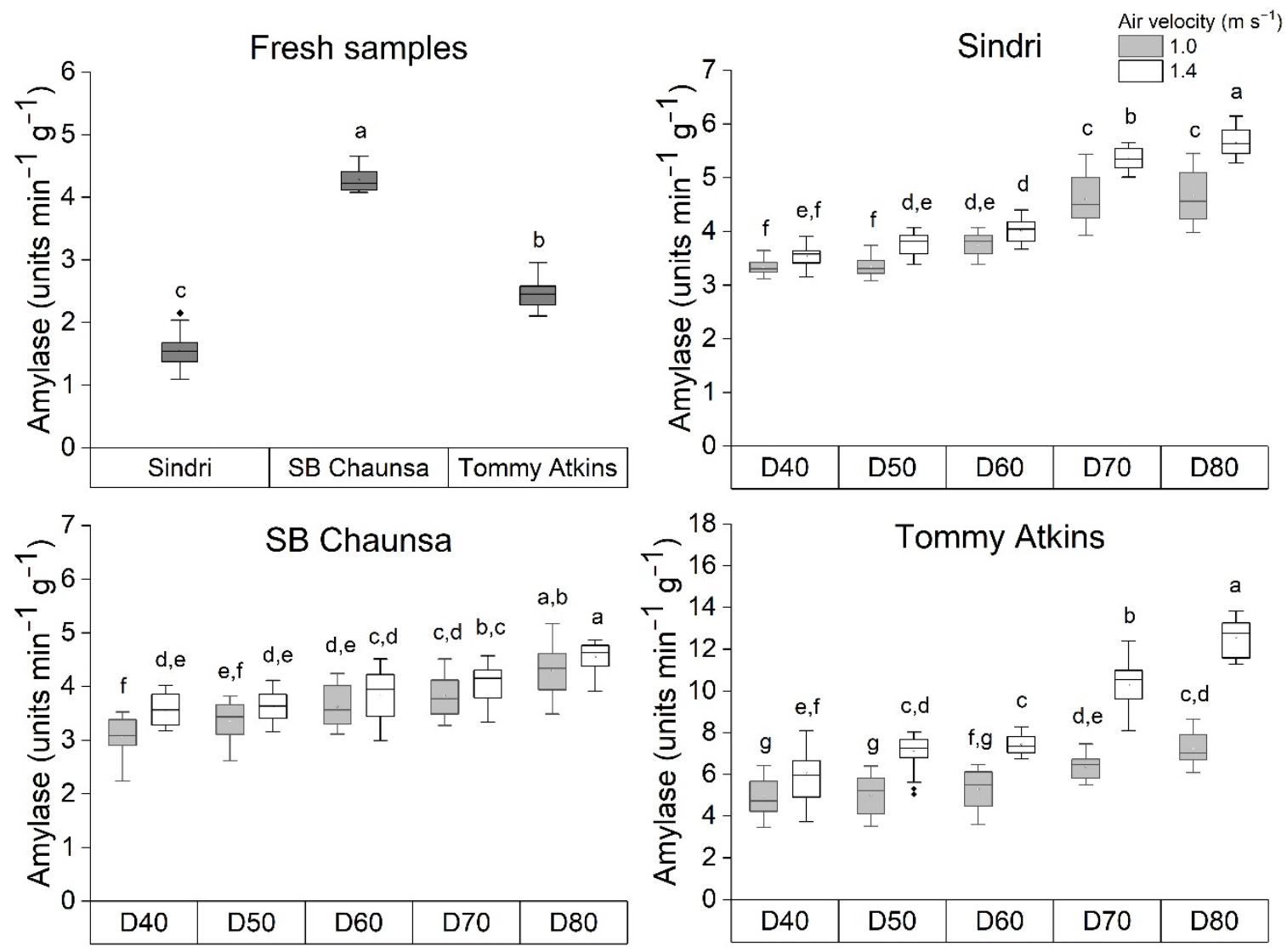

Figure 1. Amylase activity in fresh and dried mango of the varieties Sindri, SB Chaunsa, and Tommy Atkins; $\mathrm{D}=$ dried samples at temperatures $40{ }^{\circ} \mathrm{C}$ to $80^{\circ} \mathrm{C}$. a-g, different letters in the box plot indicate significant differences $p<0.05,(n=20 \times 3)$.

Furthermore, the results also revealed that an increase in air velocity from $1.0 \mathrm{~m} \mathrm{~s}^{-1}$ to $1.4 \mathrm{~m} \mathrm{~s}^{-1}$ at drying temperatures of $40{ }^{\circ} \mathrm{C}$ to $80{ }^{\circ} \mathrm{C}$ had a beneficial effect on the activity retention of amylase in dried mango of all three varieties, and helped to preserve 
4.81-42.50\% more amylase units in the final product. This behavior might be attributed to the fact that at the same drying temperature higher air velocity results in a significant reduction in drying time $[2,15]$. Thus, a decreased drying time has positively influenced the decrease in the thermal degradation of amylase. Therefore, at the same drying temperature, the samples dried at the higher air velocity of $1.4 \mathrm{~m} \mathrm{~s}^{-1}$ retained a higher amylase activity.

\subsection{Invertase Activity in Fresh and Dried Samples}

The invertase activity in fresh and dried mango of the varieties Sindri, S.B. Chaunsa, and Tommy Atkins was also analyzed, and the results are displayed in Figure 2. Invertase activity was the highest in fresh samples of Tommy Atkins (0.95-1.37 units $\left.\mathrm{min}^{-1} \mathrm{~g}^{-1}\right)$, followed by SB Chaunsa (0.93-1.21 units $\left.\min ^{-1} \mathrm{~g}^{-1}\right)$, and Sindri $\left(0.45-0.77\right.$ units $\mathrm{min}^{-1} \mathrm{~g}^{-1}$ ). During drying however, as for amylase, both the drying temperature and the air velocity showed a significant influence on the invertase activity retention in dried samples. In all three varieties, the maximum average invertase activity (3.12-9.99 units $\min ^{-1} \mathrm{~g}^{-1}$ ) was retained in samples dried at $80{ }^{\circ} \mathrm{C}$ and $1.4 \mathrm{~m} \mathrm{~s}^{-1}$ air velocity compared to those dried at lower temperatures and $1.0 \mathrm{~m} \mathrm{~s}^{-1}$ air velocity. As invertase is also a thermotolerance enzyme, this finding corroborates that the preservation of heat-resistant enzymes in dried mango is directly related to the drying time. Drying at $80{ }^{\circ} \mathrm{C}$ and air velocity of $1.4 \mathrm{~m}$ $\mathrm{s}^{-1}$ exhibited a higher moisture loss and shorter drying time compared to low drying temperatures at an air velocity of $1.0 \mathrm{~m} \mathrm{~s}^{-1}[2,13]$. Consequently, a reduction in drying time could effectively lead to the preservation of invertase in dried samples. On the other hand, many studies have also reported that prolonged heat exposure to invertase above the optimal temperature of $37^{\circ} \mathrm{C}$ causes its destruction or degradation, due to thermal denaturation of enzyme protein $[37,38]$. Thus, mango slabs dried at a low temperature required a longer drying time to remove moisture up to its target level, and eventually the invertase activity decreased.
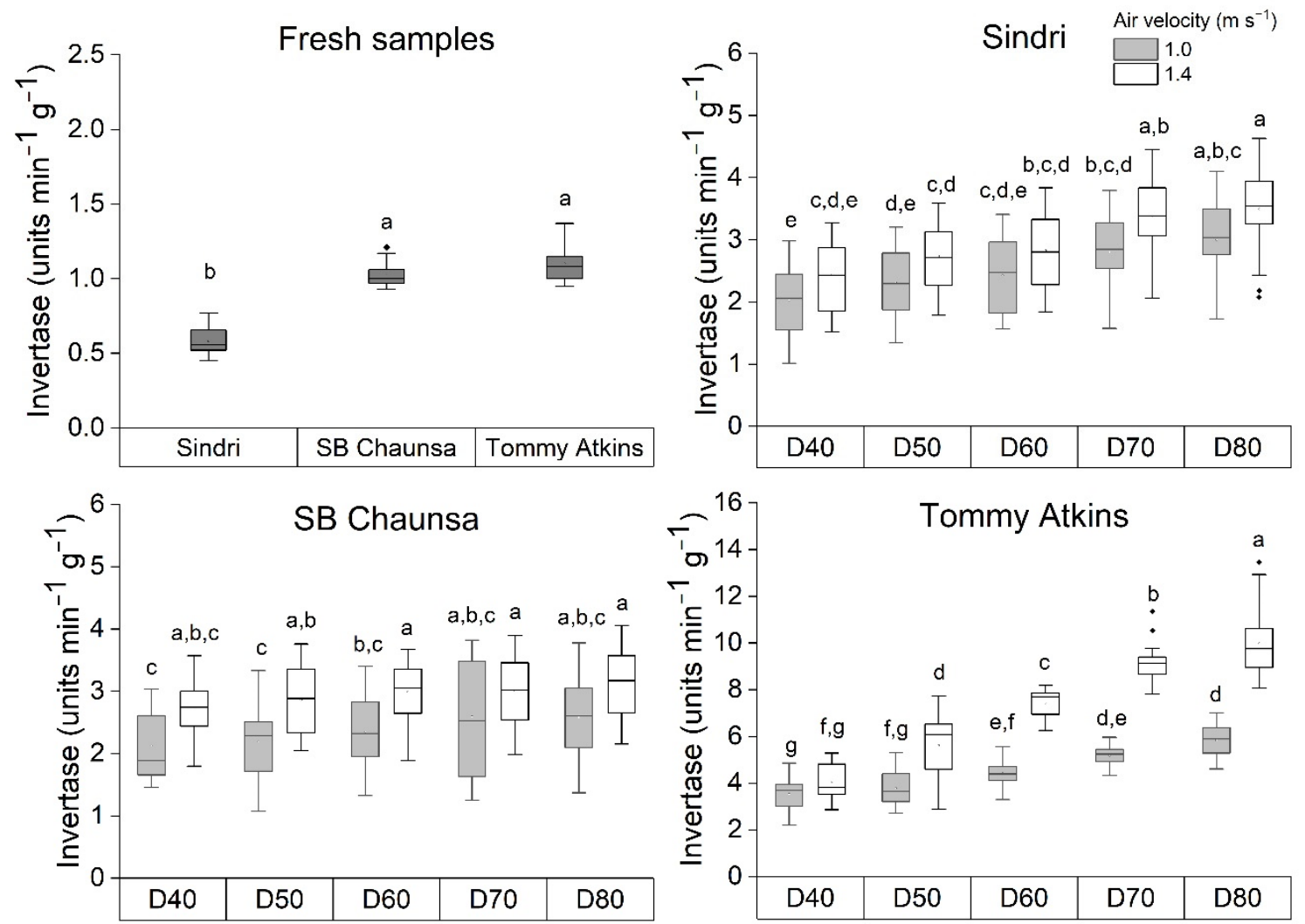

Figure 2. Invertase activity in fresh and dried mango varieties Sindri, SB Chaunsa, and Tommy Atkins; $\mathrm{D}=$ dried samples at temperatures $40{ }^{\circ} \mathrm{C}$ to $80^{\circ} \mathrm{C}$. a-g, different letters in the box plot indicate significant differences under the limit of $p<0.05$, $(n=20 \times 3)$. 


\subsection{Residual Activity of Amylase and Invertase during Mango Drying}

For a better understanding of the activity degradation of amylase and invertase along with the changes in water activity during mango drying, see Figure 3a-e. The results reveal that at an air velocity of $1.0 \mathrm{~m} \mathrm{~s}^{-1}$, drying at $40^{\circ} \mathrm{C}, 60^{\circ} \mathrm{C}$, and $80^{\circ} \mathrm{C}$ exhibited destruction rates $\left(k_{d}\right)$ for amylase of $0.0013,0.0020$, and $0.0029 \mathrm{~min}^{-1}$, and for invertase $0.0008,0.0017$, and $0.0023 \mathrm{~min}^{-1}$, respectively (Figure $\left.3 \mathrm{a}, \mathrm{c}\right)$. The maximum degradation rate $\left(\mathrm{k}_{\mathrm{d}}\right)$, both for amylase and invertase, was found at $80^{\circ} \mathrm{C}$ compared to $60^{\circ} \mathrm{C}$ and $40^{\circ} \mathrm{C}$. The related results on heat inactivation of different enzymes were also found in previous studies $[21,38,39]$. In addition, at temperatures $40{ }^{\circ} \mathrm{C}, 60^{\circ} \mathrm{C}$, and $80^{\circ} \mathrm{C}$, an increase in the air velocity to $1.4 \mathrm{~m} \mathrm{~s}^{-1}$ increased the destruction rate $\left(\mathrm{k}_{\mathrm{d}}\right)$ values of amylase $(7.57-13.13 \%)$ and invertase (7.24-14.08\%). Vega-Gálvez et al. [12] reported that the heat diffusion capacity of a high air velocity is more pronounced than that of a lower one. Therefore, it was believed that drying at $1.4 \mathrm{~m} \mathrm{~s}^{-1}$ air velocity causes a larger destruction of enzymes. Related information was also discussed in our previous study [2] where higher product surface temperature and internal temperature were observed at an air velocity of $1.4 \mathrm{~m} \mathrm{~s}^{-1}$ compared to $1.0 \mathrm{~m} \mathrm{~s}^{-1}$. Furthermore, this finding can be explained well by comparing the energy of deactivation $\left(E_{d}\right)$ values for both air velocities, $1.0 \mathrm{~m} \mathrm{~s}^{-1}$ and $1.4 \mathrm{~m} \mathrm{~s}^{-1}$, that was measured from the slope of Arrhenius plot, $\ln k_{d}$ versus reciprocal of temperature, $1 / T$ (K) (Figure 3b,d). It was found that the air velocity $1.4 \mathrm{~m} \mathrm{~s}^{-1}$ exhibited a higher $\mathrm{E}_{\mathrm{d}}$ value for amylase $(0.32 \%)$ and invertase $(6.94 \%)$ compared to an air velocity of $1.0 \mathrm{~m} \mathrm{~s}^{-1}$, confirming that more energy is involved to denature the enzyme at a higher air velocity. Hence, a larger enzyme destruction was observed at air velocity of $1.4 \mathrm{~m} \mathrm{~s}^{-1}$. Despite all these facts, the residual enzyme activity is also directly related to the drying time or heat exposure time [40]. The mango slabs dried at $80^{\circ} \mathrm{C}$ and air velocity of $1.4 \mathrm{~m} \mathrm{~s}^{-1}$ needed less time $240 \mathrm{~min}$ to reach the safe water activity level $\leq 0.6$, as it required $1080 \mathrm{~min}$ at $40^{\circ} \mathrm{C}$ and air velocity of $1.0 \mathrm{~m} \mathrm{~s}^{-1}$ (Figure 3e). Many studies have shown that prolonged drying time causes cell lysis or disruption, and could modify the biochemical reactions inside the fruits by raising their exposure to heat, light, and oxidation [41,42], which may negatively influence the activity retention of amylase and invertase in dried mango. Therefore, the mango slabs dried at $40^{\circ} \mathrm{C}$ and air velocity of $1.0 \mathrm{~m} \mathrm{~s}^{-1}$ could eventually be retaining a minimum of enzymes although the destruction rate was lower. Moreover, it is also well-known that the optimum temperature and high water activity stimulate the enzyme activity inside the fruit. During drying at a low temperature of $40{ }^{\circ} \mathrm{C}$, the amylase and invertase retained near their optimal temperature and a good water activity level for a longer duration, where they can perform their maximum activity, and may involve in self-denaturation due to accumulation of end products or unavailability of the substrate which could be verified further by measuring their end products.

\subsection{Reducing Sugar (Maltose and Glucose)}

The end products of amylase (maltose) and invertase (glucose) were evaluated in fresh samples and those dried at $40{ }^{\circ} \mathrm{C}, 60^{\circ} \mathrm{C}$, and $80^{\circ} \mathrm{C}$ (Figure $4 \mathrm{a}, \mathrm{b}$ ). The results revealed that, for all three varieties, the maltose and glucose contents varied significantly $(p<0.05)$ under different drying temperatures. The samples dried at $40{ }^{\circ} \mathrm{C}$ contained a maximum amount of maltose and glucose in the ranges $\left(25.96-44.45,22.06-27.51 \mathrm{~g} 100 \mathrm{~g}^{-1} \mathrm{~d}\right.$.w.) compared to the fresh samples (15.49-23.92, 9.77-14.10 g $100 \mathrm{~g}^{-1}$ d.w.) and those dried at $60{ }^{\circ} \mathrm{C}$ (19.18-39.80, 17.27-20.65 g $100 \mathrm{~g}^{-1}$ d.w.) and $80^{\circ} \mathrm{C}\left(16.40-25.57,12.92-17.20 \mathrm{~g} 100 \mathrm{~g}^{-1}\right.$ d.w.). These findings may be due to the fact that, during drying at $40^{\circ} \mathrm{C}$, the amylase and invertase remained active for a longer period of time, and exhibited their maximum activity, compared to drying at $60^{\circ} \mathrm{C}$ and $80^{\circ} \mathrm{C}$. Related results were also discussed in our previous study during heat incubation trials of amylase and invertase, where we found the maximum amylase and invertase activity at $40^{\circ} \mathrm{C}$ [2]. However, it has also been documented in the literature that continuous generation and accumulation of end products have a negative influence on enzyme activity by disturbing the equilibrium needed to maintain their natural 
structure and can lead to enzyme degradation $[3,33,43,44]$. Consequently, the mango slabs dried at $40{ }^{\circ} \mathrm{C}$ preserved the least amylase and invertase units.
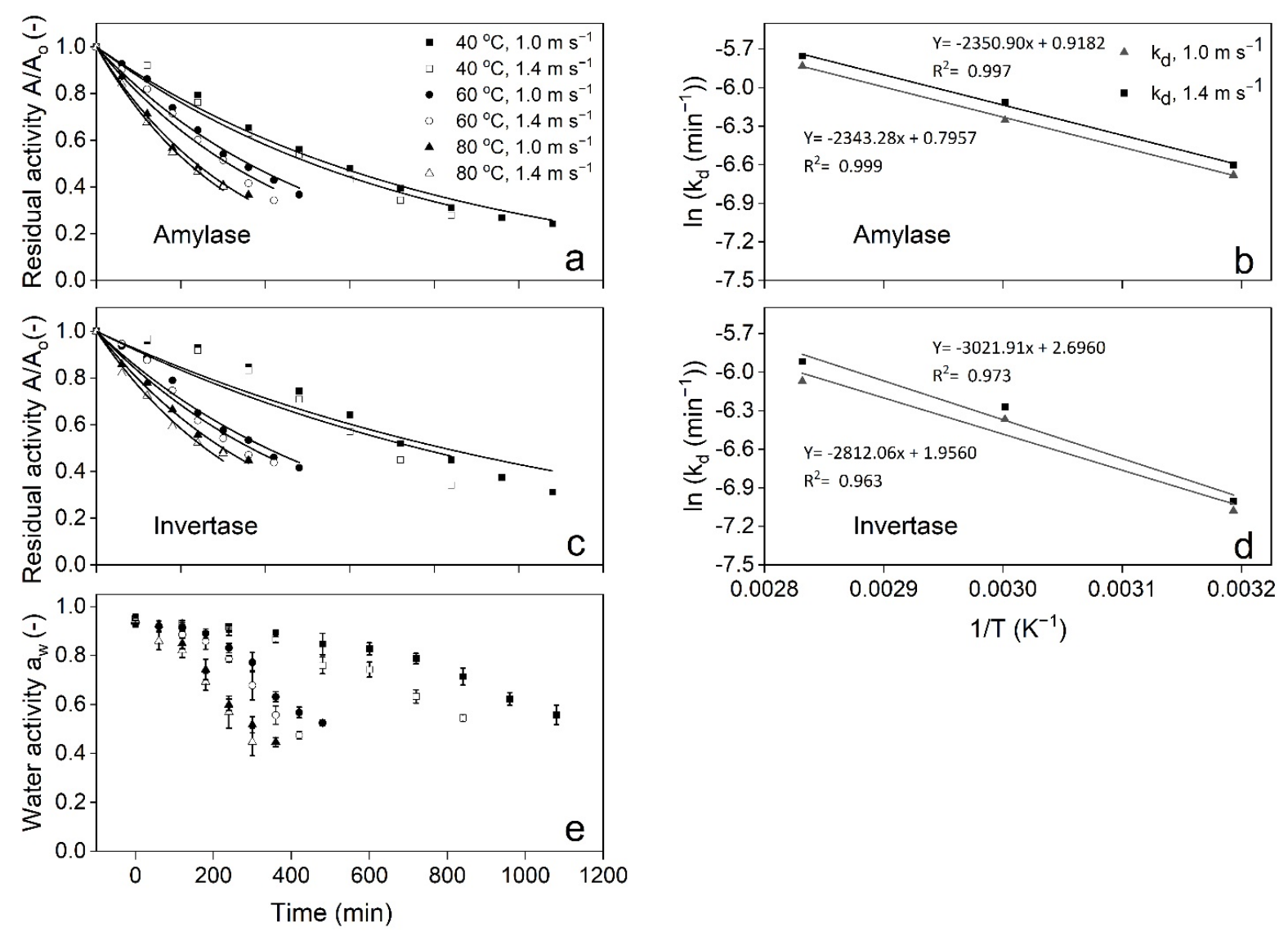

Figure 3. Residual activity $\mathrm{A} / \mathrm{A}_{\mathrm{o}}$ and Arrhenius plot for the energy of deactivation of $(\mathbf{a}, \mathbf{b})$ amylase and (c,d) invertase; and (e) water activity during drying of mango variety Sindri at $40^{\circ} \mathrm{C}, 60^{\circ} \mathrm{C}$, and $80{ }^{\circ} \mathrm{C}$; air velocity $1.0 \mathrm{~m} \mathrm{~s}^{-1}$ or $^{1.4} \mathrm{~m} \mathrm{~s}^{-1}$.
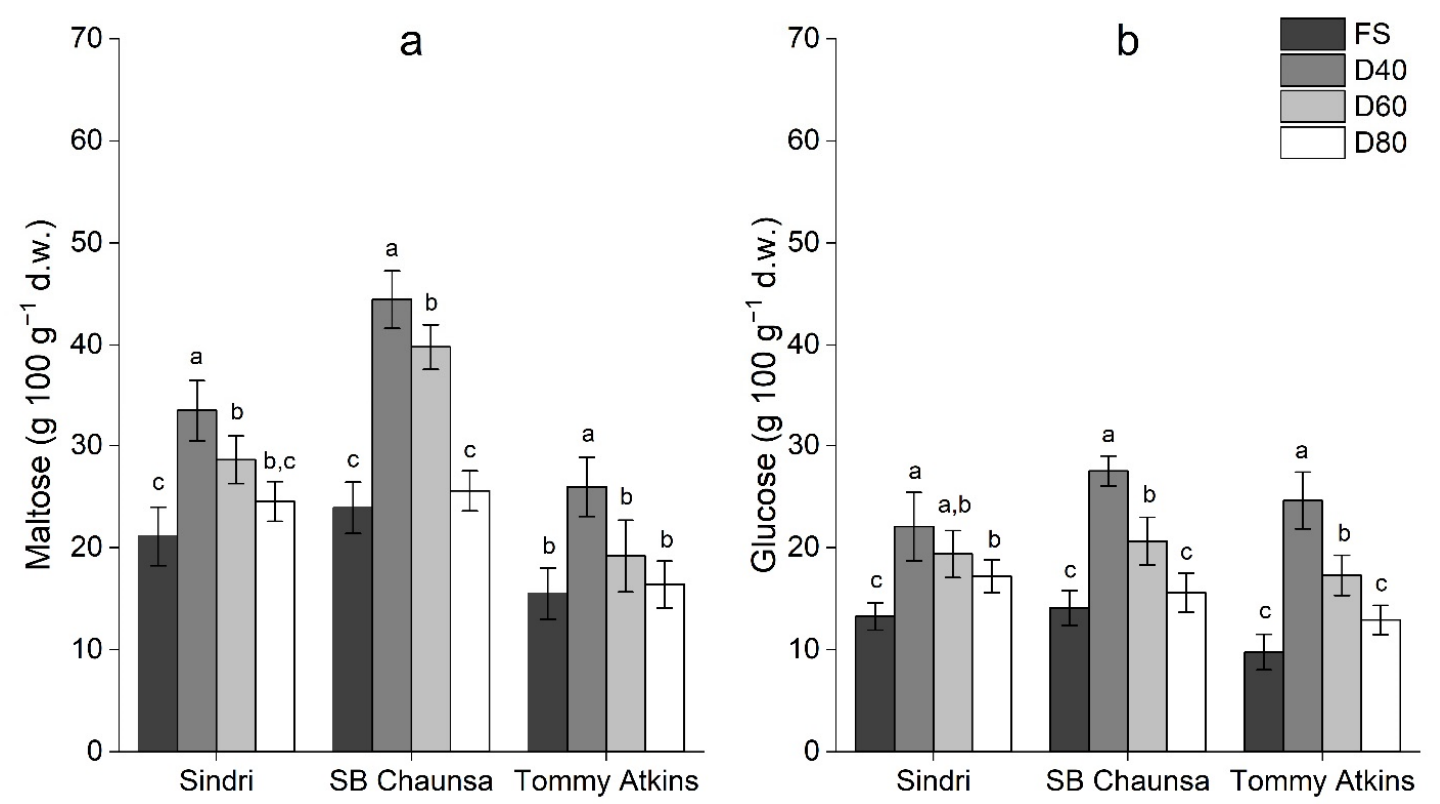

Figure 4. (a) Maltose and (b) glucose concentrations in fresh and dried samples of varieties Sindri, SB Chaunsa, and Tommy At kins; FS = fresh samples, $\mathrm{D}=$ dried samples, at temperatures $40{ }^{\circ} \mathrm{C}, 60^{\circ} \mathrm{C}$, and $80^{\circ} \mathrm{C}$. Different letters $(\mathrm{a}-\mathrm{C})$ above bars within the same variety represent significant differences $p<0.05,(n=6)$. 


\section{Conclusions}

This study showed that both the drying temperature and air velocity had a noticeable influence on the activity retention of the target enzymes, amylase and invertase, in dried mango slabs. The results for the drying kinetics of amylase and invertase revealed an increase in the destruction rate $\left(\mathrm{k}_{\mathrm{d}}\right)$ by increasing temperature and air velocity. However, increased drying temperature and air velocity significantly reduced the drying time. As the activity retention of amylase and invertase in dried mango is not only affected by the heat treatment, but also by the exposure time at high water activity, a decrease in drying time positively influenced the preservation of amylase and invertase units in dried samples. Thus, drying at $80{ }^{\circ} \mathrm{C}$ with $1.4 \mathrm{~m} \mathrm{~s}^{-1}$ air velocity preserved more enzyme units of amylase (4.55-12.56 units $\min ^{-1} \mathrm{~g}^{-1}$ ) and invertase (3.12-9.99 units $\min ^{-1} \mathrm{~g}^{-1}$ ) in the dried product. These results also highlight new possibilities of using hot-air convective drying to produce dry mango that retains a larger amount of the digestive enzymes amylase and invertase. Further research on the stability of the enzymes during storage, and their correlation with other nutritional components of mango, as well as the influence of maturity on enzymatic activity during convective drying, should be conducted.

Author Contributions: Conceptualization, A.M., S.L. and J.M.; methodology, A.M. and S.L.; software, A.M.; validation, A.M., S.L. and J.M.; formal analysis, A.M., S.L. and J.M.; investigation, A.M.; resources, A.M., S.L. and J.M.; data curation, A.M.; writing-original draft preparation, A.M.; writing-review and editing, A.M., S.L. and J.M.; visualization, A.M., S.L. and J.M.; supervision, S.L. and J.M.; project administration, A.M., S.L. and J.M.; funding acquisition, A.M., S.L. and J.M. All authors have read and agreed to the published version of the manuscript.

Funding: This research was funded by a Faculty grant (PS-2(11)FDP/15/22241) from the University of Agriculture, Faisalabad, Pakistan.

Institutional Review Board Statement: Not applicable.

Informed Consent Statement: Not applicable.

Data Availability Statement: Not applicable.

Acknowledgments: We are thankful to our lab team, Institute of Agricultural Engineering (440e), Tropics and Subtropics Group, for their technical support and Sabine Nugent for the English proofreading of this manuscript.

Conflicts of Interest: The authors declare no conflict of interest.

\section{References}

1. Sulistyawati, I.; Verkerk, R. Consumer preference for dried mango attributes: A conjoint study among Dutch, Chinese, and Indonesian consumers. J. Food Sci. 2020, 85, 3527-3535. [CrossRef]

2. Mukhtar, A.; Latif, S.; Mueller, J. Effect of Heat Exposure on Activity Degradation of Enzymes in Mango Varieties Sindri, SB Chaunsa, and Tommy Atkins during Drying. Molecules 2020, 25, 5396. [CrossRef] [PubMed]

3. Hossain, M.A.; Rana, M.M.; Kimura, Y.; Roslan, H.A. Changes in biochemical characteristics and activities of ripening associated enzymes in mango fruit during the storage at different temperatures. Biomed Res. Int. 2014, 14, 232969. [CrossRef] [PubMed]

4. Sarkar, T.; Saha, S.K.; Salauddin, M.; Chakraborty, R. Drying Kinetics, Fourier-Transform Infrared Spectroscopy Analysis and Sensory Evaluation of Sun, Hot-Air, Microwave and Freeze Dried Mango Leather. J. Microbiol. Biotechnol. Food Sci. 2021, 10, e3313. [CrossRef]

5. Yan, J.K.; Wu, L.X.; Qiao, Z.R.; Cai, W.D.; Ma, H. Effect of different drying methods on the product quality and bioactive polysaccharides of bitter gourd (Momordica charantia L.) slices. Food Chem. 2019, 271, 588-596. [CrossRef]

6. De Ancos, B.; Sánchez-Moreno, C.; Zacarías, L.; Rodrigo, M.J.; Sáyago Ayerdí, S.; Blancas Benítez, F.J.; Domínguez Avila, J.A.; González-Aguilar, G.A. Effects of two different drying methods (freeze-drying and hot air-drying) on the phenolic and carotenoid profile of 'Ataulfo' mango by-products. J. Food Meas. Charact. 2018, 12, 2145-2157. [CrossRef]

7. Calín-Sánchez, Á.; Lipan, L.; Cano-Lamadrid, M.; Kharaghani, A.; Masztalerz, K.; Carbonell-Barrachina, Á.A.; Figiel, A. Comparison of traditional and novel drying techniques and its effect on quality of fruits, vegetables and aromatic herbs. Foods 2020, 9, 1261. [CrossRef]

8. Mutuli, G.P.; Gitau, A.N.; Mbuge, D.O. Convective Drying Modeling Approaches: A Review for Herbs, Vegetables, and Fruits. J. Biosyst. Eng. 2020, 45, 197-212. [CrossRef] 
9. Wen Chua, L.Y.; Chua, B.L.; Figiel, A.; Chong, C.H.; Wojdyło, A.; Szumny, A.; Lech, K. Characterisation of the convective hot-air drying and vacuum microwave drying of cassia alata: Antioxidant activity, essential oil volatile composition and quality studies. Molecules 2019, 24, 1625. [CrossRef]

10. Zhu, A. The convective hot air drying of Lactuca sativa slices. Int. J. Green Energy 2018, 15, 201-207. [CrossRef]

11. Şen, S.; Aydin, F. Experimental investigation of drying kinetics of apple with hot air, microwave and ultrasonic power. Sadhana 2020, 45, 94. [CrossRef]

12. Vega-Gálvez, A.; Ah-Hen, K.; Chacana, M.; Vergara, J.; Martínez-Monzó, J.; García-Segovia, P.; Lemus-Mondaca, R.; Di Scala $\mathrm{K}$. Effect of temperature and air velocity on drying kinetics, antioxidant capacity, total phenolic content, colour, texture and microstructure of apple (var. Granny Smith) slices. Food Chem. 2012, 132, 51-59. [CrossRef]

13. Udomkun, P.; Argyropoulos, D.; Nagle, M.; Mahayothee, B.; Janjai, S.; Müller, J. Single layer drying kinetics of papaya amidst vertical and horizontal airflow. LWT Food Sci. Technol. 2015, 64, 67-73. [CrossRef]

14. Diop, A.; Méot, J.M.; Léchaudel, M.; Chiroleu, F.; Ndiaye, N.D.; Mertz, C.; Cissé, M.; Chillet, M. Impact of preharvest and postharvest on color changes during convective drying of mangoes. Foods 2021, 10, 490. [CrossRef] [PubMed]

15. Russo, P.; Adiletta, G.; Di Matteo, M.; Farina, V.; Corona, O.; Cinquanta, L. Drying kinetics and physico-chemical quality of mango slices. Chem. Eng. Trans. 2019, 75, 109-114. [CrossRef]

16. Putra, R.N.; Ajiwiguna, T.A. Influence of air temperature and velocity for drying process. Procedia Eng. 2017, 170, 516-519. [CrossRef]

17. Mishra, M.; Kandasamy, P.; Nath Shukla, R.; Kumar, A. Convective Hot-air Drying of Green Mango: Influence of Hot Water Blanching and Chemical Pretreatments on Drying Kinetics and Physicochemical Properties of Dried Product. Int. J. Fruit Sci. 2021, 21, 732-757. [CrossRef]

18. Sehrawat, R.; Nema, P.K.; Kaur, B.P. Quality evaluation and drying characteristics of mango cubes dried using low-pressure superheated steam, vacuum and hot air drying methods. LWT Food Sci. Technol. 2018, 92, 548-555. [CrossRef]

19. Omolola, A.O.; Jideani, A.I.O.; Kapila, P.F. Quality properties of fruits as affected by drying operation. Crit. Rev. Food Sci. Nutr. 2017, 57, 95-108. [CrossRef]

20. Izli, N.; Izli, G.; Onur, T. Influence of different drying techniques on mango. Food Sci. Technol. 2017, 37, 604-612. [CrossRef]

21. Illera, A.E.; Sanz, M.T.; Benito-Román, O.; Varona, S.; Beltrán, S.; Melgosa, R.; Solaesa, A.G. Effect of thermosonication batch treatment on enzyme inactivation kinetics and other quality parameters of cloudy apple juice. Innov. Food Sci. Emerg. Technol. 2018, 47, 71-80. [CrossRef]

22. Adetoro, A.O.; Opara, U.L.; Fawole, O.A. Effect of blanching on enzyme inactivation, physicochemical attributes and antioxidant capacity of hot-air dried pomegranate (Punica granatum 1.) arils (cv. wonderful). Processes 2021, 9, 25. [CrossRef]

23. Osae, R.; Essilfie, G.; Alolga, R.N.; Akaba, S.; Song, X.; Owusu-Ansah, P.; Zhou, C. Application of non-thermal pretreatment techniques on agricultural products prior to drying: A review. J. Sci. Food Agric. 2020, 100, 2585-2599. [CrossRef]

24. Argyropoulos, D.; Heindl, A.; Müller, J. Assessment of convection, hot-air combined with microwave-vacuum and freeze-drying methods for mushrooms with regard to product quality. Int. J. Food Sci. Technol. 2011, 46, 333-342. [CrossRef]

25. AOAC Int. Official Methods of Analysis, 17th ed.; Association of Official Analytical Chemists: Arlington, VA, USA, 2000.

26. Defraeye, T. Impact of size and shape of fresh-cut fruit on the drying time and fruit quality. J. Food Eng. 2017, $210,35-41$. [CrossRef]

27. Minuye, M.; Getachew, P.; Baye, K.; Laillou, A.; Chitekwe, S. Effects of different drying methods and ascorbic acid pretreatment on carotenoids and polyphenols of papaya fruit in Ethiopia. Food Sci. Nutr. 2021, 9, 3346-3353. [CrossRef]

28. Cichowska, J.; Kowalska, H. Effect of osmotic pre-treatment and temperature storage conditions on water activity and colour of dried apple. Int. J. Food Eng. 2018, 14, 20170158. [CrossRef]

29. Zakir, H.M.; Fardush, J.; Hossain, M.S.; Islam, M.Z.; Shariar, S.M.S.; Rokshana, K.; Hossian, M. Effects of storage temperatures on different biochemical characteristics of 1-methylcyclopropene treated mango (Mangifera Indica L.) variety Khirshapat. Am. J. Food Sci. Technol. 2018, 6, 76-82.

30. Li, R.; Shang, H.; Wu, H.; Wang, M.; Duan, M.; Yang, J. Thermal inactivation kinetics and effects of drying methods on the phenolic profile and antioxidant activities of chicory (Cichorium intybus L.) leaves. Sci. Rep. 2018, 8, 9529. [CrossRef] [PubMed]

31. Miłek, J. Application of the new method to determine the activation energies and optimum temperatures of inulin hydrolysis by exo-inulinases Aspergillus niger. J. Therm. Anal. Calorim. 2021, 1-7. [CrossRef]

32. Miller, G.L. Use of dinitrosalicylic acid reagent for determination of reducing sugar. Anal. Chem. 1959, 31, 426-428. [CrossRef]

33. De Lima, L.C.O.; Chitarra, A.B.; Chitarra, M.I.F.; Carlos De Oliveira Lima, L.; Chitarra, A.B.; Isabel, M.; Chitarra, F. Changes in amylase activity starch and sugars contents in mango fruits pulp Cv. Tommy Atkins with spongy tissue. Braz. Arch. Biol. Technol. 2001, 44, 59-62. [CrossRef]

34. Terebiznik, M.R.; Buera, M.P.; Pilosof, A.M.R. Thermal Stability of Dehydrated $\alpha$-Amylase in Trehalose Matrices in Relation to its Phase Transitions. LWT Food Sci. Technol. 1997, 30, 513-518. [CrossRef]

35. Turner, N.A.; Vulfson, E.N. At what temperature can enzymes maintain their catalytic activity? Enzym. Microb. Technol. 2000, 27, 108-113. [CrossRef]

36. Samborska, K.; Witrowa-Rajchert, D.; Gonçalves, A. Spray-drying of $\alpha$-amylase-The effect of process variables on the enzyme inactivation. Dry. Technol. 2005, 23, 941-953. [CrossRef] 
37. Warchol, M.; Perrin, S.; Grill, J.P.; Schneider, F. Characterization of a purified $\beta$-fructofuranosidase from Bifidobacterium infantis ATCC 15697. Lett. Appl. Microbiol. 2002, 35, 462-467. [CrossRef]

38. Bassetti, F.J.; Bergamasco, R.; Moraes, F.F.; Zanin, G.M. Thermal stability and deactivation energy of free and immobilized invertase. Braz. J. Chem. Eng. 2000, 17, 867-872. [CrossRef]

39. De Jesus, S.S.; Maciel Filho, R. Drying of $\alpha$-amylase by spray drying and freeze-drying-A comparative study. Braz. J. Chem. Eng. 2014, 31, 625-631. [CrossRef]

40. Scanlon, M.G.; Henrich, A.W. 13-Factors Affecting Enzyme Activity in Food Processing. In Proteins in Food Processing, 2nd ed.; Yada, R.Y., Ed.; Woodhead Publishing: Sawston, UK, 2018; pp. 337-365.

41. Guiné, R.P.F. The Drying of Foods and Its Effect on the Physical-Chemical, Sensorial and Nutritional Properties. Int. J. Food Eng. 2018, 4, 93-100. [CrossRef]

42. Udomkun, P.; Nagle, M.; Mahayothee, B.; Nohr, D.; Koza, A.; Müller, J. Influence of air drying properties on non-enzymatic browning, major bio-active compounds and antioxidant capacity of osmotically pretreated papaya. LWT Food Sci. Technol. 2015, 60, 914-922. [CrossRef]

43. Chakraborty, S.; Baier, D.; Knorr, D.; Mishra, H.N. High pressure inactivation of polygalacturonase, pectinmethylesterase and polyphenoloxidase in strawberry puree mixed with sugar. Food Bioprod. Process. 2015, 95, 281-291. [CrossRef]

44. Rahman, M.; Absar, N.; Ahsan, M. Correlation of carbohydrate content with the changes in amylase, invertase and galactosidase activity of ripe mango pulp during storage under different temperatures. Bangladesh J. Sci. Ind. Res. 2011, 46, 443-446. [CrossRef] 